Љиљана Бајић

ica.bajic@gmail.com

Универзитет у Београду

Филолошки факултет
УДК 811.163.41:378 (100)

061.6:811.163.41(100)

https://doi.org/10.18485/mks_knsjkk_polozaj.2020.ch1

\title{
СРПСКИ ЛЕКТОРАТИ И ЦЕНТРИ НА УНИВЕРЗИТЕТИМА У СВЕТУ (СТАҢЕ И ПЕРСПЕКТИВЕ)
}

У раду се износе актуелне прилике србистике и српских лектората у свету. Образлажући ову тему у инословенској средини, аутор истиче потребу за развијањем адекватне методике упоредних студија и наставе српског језика, књижевности и културе, сагледаних у контакту са другим словенским језицима и културама.

Кључне речи: српски лекторати, статус српског језика, књижевност, култура, перспективе развоја.

Осврт на тему, која је посвећена актуелним приликама и перспективама србистике у свету, почињемо навођењем угледног примера из историје проучавања српског језика/српскохрватског језика на Факултету за филологију и уметност Државног универзитета у Санкт Петербургу.

Два су разлога томе. Прво, Државни универзитет у Санкт Петербургу, основан указом Петра Великог 28. јанура 1724. године, има историју дугу скоро три века. Она чува имена многих великих филолога, у првом реду, Ломоносова. На Катедри за словенску филологију Универзитета у Санкт Петербургу, основаној средином 19. века, радили су и њом руководили од самог почетка неки од највећих лингвиста, као што су Срезњевски и В. Јагић (Керкез 2016: 437). Средином 20. века, 1944. године на Катедри за славистику почињу се одржавати предавања из историје српске књижевности, са којима српски језик стиче место међу другим словенским језицима који се овде студирају. Предавања су била интензивирана посебно у периоду од 1964. до 1998. године, када су на челу Катедре за словенску филологију били истакнути ср- 
бисти, професори Дмитријев и Сафронов (Дракулић-Пријма 2016: 425), а захваљујући напору и преданом раду тамошњих посленика (Дракулић-Пријма, Трофимкина и други) србистика је очувана и до наших дана. Најзад, 2014. године она је овде обележила 70 година свога постојања.

Други разлог који нас наводи да подсетимо на пример једног од најзначајнијих славистичких центара у свету повезује се са чињеницом да су у њему, као и у другим центрима на европским и светским универзитетима последњих година 20. и почетком 21. века, наступиле околности у којима је, показало се, услед отежених услова за рад очување србистике постало угрожено.

Друштвенополитичке прилике и превирања деведесетих година 20. века на већем делу јужнословенског геополитичког и културног простора утицале су на промене у организацији и раду дотадашњих југословенских лектората српскохрватског, словеначког и македонског језика. У време распада државне и језичке заједнице ова кретања довела су до формирања националних лектората у оквиру славистичких катедара и центара на универзитетима у свету. У таквим приликама многе високообразовне установе нашле су се пред потребом да редефинишу студијске програме и ускладе их са социолингвистичким променама које су се на српскохрватском језичком простору почеле дешавати током последњих година прошлог века. Наставна пракса у тој области данас је врло различита. Као пример поменућемо да се новонастали стандардни језици - српски, хрватски, босански, црногорски - негде изучавају у оквиру једног/истог предмета, као један језик уз истицање посебности сваког од тих појединачних стандарда. Такав статус има српски као страни језик на неким универзитетима у САД. Али иако учење и студирање српског језика у овој земљи има дугу традицију (од осамдесетих година 20. века српскохрватски језик био је заступљен на више од 52 универзитета, колеџа и више школа у САД), интересовање за студије српског језика, према изворима у литератури, знатно је мање, а број уписаних студената, различит од универзитета до универзитета, сем на Универзитету у Мичигену, углавном опада (Росић 2016: 421). 
Не улазећи у научну, лингвистичку и наставну природу ове језичке материје, истичемо начелно становиште о томе да због своје трајне важности српски лекторати у Европи и свету ваља да буду на врху приоритета државне, језичке, образовне и културне политике, а афирмација, професионализација, осавремењавања и усавршавања лекторског занимања део дугорочне националне стратегије и бриге за српски језик и књижевност на страним универзитетима.

Изучавање књижевности и културе на српском језику као тзв. малом језику део је националног, образовног, научног и културног програма, који креирају и спроводе надлежне високошколске и државне институције у земљи. Ове године, на основу заједничког става Министарства просвете, науке и технолошког развоја, Министарства културе и информисања, Министарства спољних послова и Филолошког факултета Универзитета у Београду, одлучено је да се код нас оснује посебна радна група за лекторате српског језика која, ценећи заједничку одговорност свих поменутих институција за развој ове области, разматра законску и подзаконску регулативу за њено уређивање, утврђује одговарајуће процедуре за деловање у њој и припрема упутство о условима за избор лектора српског језика и књижевности на страним високошколским установама. Оперативне мере предузете су са циљем да се српски лекторати и центри у Европи и свету боље уреде и да им се, уз побољшане материјалне, организационе и стручне услове, омогући да унапреде своју делатност и развијају се. Упутством се прописују услови, поступак избора, права и обавезе лектора за време ангажовања, састав и надлежност Комисије за лекторе у спровођењу избора и програму стручног усавршавања за унапређивање акедемских и наставничких компетенција лектора, те делатност факултета у реализацији програма обуке и усавршавања лектора у оквиру стручних и академских активности на факултетима. Предвиђа се да за лекторско занимање може бити изабрана особа која има завршене основне студије српског језика и књижевности, или студије филологије и мастер студије српског језика и књижевности, или српског језика као страног, или мастер филологије на једном од универзитета у Републици 
Србији; зна један светски језик/језик земље пријема на нивоу Б1 Заједничког европског оквира. У складу са знањима која треба да поседује у настави српског као страног и српског као инословенског језика, предност при избору има кандидат са завршеним студијама у области српског језика и књижевности, кандидат са највећом просечном оценом на основним и мастер студијама, кандидат са објављеним радовима и наградама, кандидат са радним искуством. Делокруг лекторских послова упутсвом се сажима на следеће задатке: лектори су обавезни да држе предавања и изводе практичне вежбе из српског језика, српске књижевности и културе, а по потреби и предавања из историје језика, дијалектологије, културне историје Срба и других сродних дисциплина, преносећи и афирмишући нашу културну и уметничку баштину. У оквиру програма припреме за лекторско занимање они се упућују на стручно усавршавање у славистичке центре и центре за српски језик као страни на факултетима у Србији. Са задовољством се може констатовати да је иницијатива за доношење правилника којим се регулишу ближи услови у погледу избора, програма рада и други услови за рад лектора, дала резултате: 2019. године, у августу месецу, дати правилник ступио је на снагу.

Глобализација савременог света утиче на статус језика у образовним системима, на карактер и садржај хуманистичког образовања, на међукултурну и научну комуникацију, а у том смислу и на савремене студије српског језика, књижевности и културе. У наше доба, које карактерише интердисциплинарност појава у отвореном образовном простору, проучавање српског језика, књижевности и културе шири се ка културолошким студијама, филмским студијама, друштвеним студијама, ка антропологији, историји и другим областима. Учећи српски језик, студенти упознају историјске и савремене токове нашег живота, културу свакодневног живљења, систем вредности, нашу традицију и веровања, али и регионалне културе и друге језичке заједнице, што све захтева шире стручно знање и адекватно методичко образовање лектора.

Студије и настава српског језика, књижевности и културе на универзитетима и школама у свету разликују се међу собом 
у мери у којој се разликују предмети и области/појаве којима се оне баве. Међу српским славистима углавном је прихваћено становиште по коме се издвајају три вида изучавања словенских језика и то као матерњих, инословенских и страних. Разложно се истиче потреба за развијањем посебне методике изучавања српског и осталих словенских језика као инословенских, али се ова грана методике није конституисала као кохерентна и посебна у методолошком и теоријском смислу. Па ипак, може се закључити да су одређене методе, као што је метода конфронтационе анализе у настави словенских језика у инословенским срединама и метода компаративног проучавања књижевног текста у инословенском контексту заузеле значајно место у нашој лингводидактици, методици наставе књижевности и лигвокултурологији. Савремена лингводидактика, на пример, развија методологију међујезичког и међукултурног конфронтирања норми, традиције и средстава комуникационог понашања, сличности и разлике међу језицима и културама које се као предмет изучавања и поређења доводе у контакт (Кончаревић 2016: 327). Са друге стране, идеја о упоредној словенској књижевности има своју основу у сродности језика који, како је писао Јакобсон, обједињује Словене, у припадности словенских језика истој језичкој групи, у заједничком митолошком и фолклорном наслеђу Словена. Дуга традиција културних односа била је подстицај за прве кораке културних посленика (Шафарик, Колар и други), а касније и за упоредно проучавање појединих словенских књижевности на универзитетима (Москва, Петровград, Варшава, Праг, Београд и други) од 19. века до нашег времена, у коме су геополитичке и друштвене промене актуализовале дијалог регионалних култура и проучавање култура словенских народа.

Када је у питању настава српског језика и књижевности у словенском свету, у њој би се уз проучавање српске књижевности могао остваривати и увид у сродне словенске књижевности и тако обезбедити већи прираштај знања и оснажити језичке и читалачке компетенције студената. Ширење поља интересовања од српске ка словенским књижевностима било би од значаја за упоредно истраживање појава у књижевности и култури које се 
одвијају у сфери интертекстуалности и културног дијалога. Прилазећи предметима (језик, књижевност, култура) које треба проучити упоредо, лекторска настава српског језика и књижевности у инословенској средини истиче гледишта на компаратистичке сличности у национално и етнички обележеној литератури и култури, али и значај културног алтеритета, показујући да препознавање језичких, књижевних и културних разлика служи узајамном познавању и богаћењу појединачних језика, књижевности и култура. Развијајући се у складу са овим потребама, методика упоредних студија и наставе језика и књижевности, омогућила би подизање нивоа језичког знања и књижевне културе лектора и стварала предуслове за њихову комуникацију са другим књижевностима и културама. Проширујући истраживачко поље са језика и књижевности ка култури, она у виду има и нове правце њиховог изучавања у доба мултикултурализма, као и методичку теорију и праксу упоредног проучавања књижевности са другим текстовима културе у модерном свету испреплетаних заједница и културних идентитета.

На крају овог излагања, које је због временског ограничења нужно сведено на само неке стручне и методичке аспекте стања и перспектива српских лектората, истичемо резултате развоја србистичких студија кроз отварање српских центара на Државном универзитету „Н.И. Лобачевски” у Нижњем Новгороду и Државном лингвистичком универзитету у Бакуу, као и потребу да се ова област рада у предстојећем периоду интензивније развија.

\section{ЦИТИРАНА ЛИТЕРАТУРА}

Бајић Љ. „Књижевни текст и настава словенских језика”. Актуелни теоријско-методолошки проблеми проучавања и наставе словенских језика, књижевности и култура. (2018): 11-25.

Дракулић-Пријма Д. „Рад Одсека за српски језик на санктпетербуршком Државном универзитету у 2013/2014. школској години". Cpnски као страни језик у теорији и пракси III (2016): 425-435.

Керкез Д. „Србистика у Санкт Петербургу”. Српски као страни језик у теорији и пракси III (2016): 437-441. 
Кончаревић К. „Лингводидактички аспект конфронтационог проучавања српске комуникационе културе у инословенској (руској) средини". Српски као страни језику теорији и пракси III (2016): 323-332.

Росић М. „Статус српског као страног језика у САД”. Српски као страни језик у теорији и пракси III (2016): 421-424.

\section{ПРЕПОДАВАНИЕ СЕРБСКОГО ЯЗЫКА И СЕРБСКИЕ ЦЕНТРЫ В УНИВЕРСИТЕТАХ МИРА (СОСТОЯНИЕ И ПЕРСПЕКТИВЫ)}

В докладе рассматриваются современное состояние сербистики и актуальные проблемы преподавания сербского языка в мире. Анализируя положение сербистики в инославянской среде, автор приходит к выводу о необходимости разработки адекватной университетской методики преподавания сербского языка, литературы и культуры в сравнении с другими славянскими языками и культурами.

Ключевые слова: преподавание сербского языка, состояние сербского языка, литература, культура, перспективы развития 